Beyond the Politics of the Closet 
This page intentionally left blank 


\title{
BEYOND THE POLITICS OF THE CLOSET
}

Gay Rights and the American State Since the 1970s

\author{
EDITED BY \\ Jonathan Bell
}

\section{$\overline{\text { PENN }}$}

UNIVERSITY OF PENNSYLVANIA PRESS

PHILADELPHIA 
Copyright $\odot 2020$ University of Pennsylvania Press

All rights reserved. Except for brief quotations used for purposes of review or scholarly citation, none of this book may be reproduced in any form by any means without written permission from the publisher.

$$
\begin{gathered}
\text { Published by } \\
\text { University of Pennsylvania Press } \\
\text { Philadelphia, Pennsylvania 19104-4112 } \\
\text { www.upenn.edu/pennpress }
\end{gathered}
$$

Printed in the United States of America on acid-free paper $109 \begin{array}{lllllllll} & 8 & 7 & 6 & 5 & 4 & 3 & 2 & 1\end{array}$

A catalogue record for this book is available from the Library of Congress.

ISBN 978-0-8122-5185-2 